Crown, S. \& D'Ardenne, P. (1982) Symposium on sexual dysfunction: controversies, methods, results. British Journal of Psychiatry, 140, 70-77.

Ho, D. Y. F. (1986) Chinese patterns of socialisation: a critical review. In The Psychology of the Chinese People (ed. M. H. Bond), pp. 1-37. Hong Kong: Oxford University Press.

\section{Bipolar Affective Disorder and Thalassaemia Minor - A Genetic Linkage?}

SIR: We report a woman with thalassaemia minor and bipolar affective disorder.

Case report: An Italian woman presented for the first time at the age of 35 years in 1976 with an unipolar depressive episode requiring ECT. Since then she has been admitted on seven occasions, mostly suffering from manic episodes. Her last admission was in July 1984. She also had a concomitant history of thalassaemia minor and was noted to be anaemic on several of her admissions, requiring blood transfusions. Only one other relative, a brother, had bipolar affective disorder, but in his case no evidence of thalassaemia minor was found. Our patient responded well to conventional treatment while in hospital, but was extremely noncompliant regarding follow-up and medication. On her last admission she was noted to have splenomegaly (3 fingers), with haemoglobin of $9.5 \mathrm{~g} / 100 \mathrm{ml}$. Her blood film showed evidence of hypochromasia, microcytes, basophilic stipling, and tear drop cells. She required transfusion on this occasion.

An extensive literature search revealed only one previous case report of this kind (Joffe et al, 1986). In our case we were able to confirm haematologically the diagnosis of thalassaemia minor, and an interview with the patient's brother confirmed his diagnosis of bipolar affective disorder. Genetic linkage studies of bipolar affective disorder to date have yielded conflicting results. However, some studies have supported an X-chromosome transmission hypothesis using $\mathbf{X}$-linked colour blindness (Mendlewicz et al, 1979) and glucose-6-phosphate dehydrogenase deficiency as genetic markers (Berrettini et al, 1984). Joffe et al (1986) state that their case study provided evidence suggestive of a relationship and a possible linkage between bipolar affective disorder and thalassaemia minor. They speculated that since the short arm of chromosome II contains the adult $\beta$-globin gene and partial deletion of this gene leads to the heterozygous form of $\beta$ thalassaemia, that a possible site for the gene locus conferring susceptibility to affective disorder may occur on this chromosome. We are loath to further speculate on this, the second reported case. Perhaps a systematic review of susceptible populations, e.g. countries bordering the Mediterranean, might be worth considering.

ASHOK N. SINGH

St Brigid's Hospital

JAMES MAGUIRE

Ardee

Co. Louth

Eire

\section{References}

Berrettin, W. H., Goldin, L. R. \& Nurnberger, J. I. (1984) Genetic factors in affective illness. Journal of Psychiatric Research, 18, 329-350.

JofFe, R. T., Horvath, Z. \& TARVydas, I. (1986) Bipolar affective disorder and thalassaemia minor. American Journal of Psychiatry, 143, 933.

Mendlewicz, J., Linkowski, P., Gurofr, J. J. \& Van Pragg, H. M. (1979) Colour blindness linkage to bipolar manic-depressive illness. Archives of General Psychiatry, 36, 1442-1449.

\section{"Afiective Disorders in the Elderly"}

SIR: May I briefly comment on the review of this book (Journal, November 1987, 151, 716). Dr Garry Blessed, a well-known figure in geriatric psychiatry, provides what might be called a bluff review. His particular comment on our chapter on the relationship between physical illness and depression, wherein we looked at interactions, is that it clouds rather than clarifies.

Unfortunately for Dr Blessed, clinical horse sense is no longer good enough and multivariate analysis is with us, whether we like it or not. It may seem inchoate at times, but it has rendered simplistic clinical statements obsolete.

\section{R. EASTWOOD}

Departments of Psychiatry, and

Preventive Medicine and Biostatistics

University of Toronto

Canada 